\title{
Effects of organic compost, gypsum, and topdress sulfur rates on bioactive compounds and physicochemical characteristics of collard greens
}

Compostos bioativos e caracterização físico-química da couve-de-folha sob composto orgânico, gessagem e doses de enxofre em cobertura

\author{
M. D. Nasser ${ }^{1 *}$; A. I. I. Cardoso²; R. L. Vieites ${ }^{2}$; F. A. C. M. Nasser²; K. A. \\ Furlaneto $^{2}$; J. A. Ramos' ; P. K. Caetano' $;$ J. A. Santos ${ }^{2}$ \\ ${ }^{1}$ Polo Regional Alta Paulista, Agência Paulista de Tecnologia dos Agronegócios, APTA, 17800-000, Adamantina - SP, \\ Brasil \\ ${ }^{2}$ Departamento de Horticultura, Universidade Estadual Paulista "Júlio de Mesquita Filho" (UNESP), 18610-034, \\ Botucatu-SP, Brasil \\ *mdnasser@apta.sp.gov.br
}

(Recebido em 10 de outubro de 2019; aceito em 18 de setembro de 2020)

\begin{abstract}
This study evaluates the use of sulfur, gypsum, and organic compost as to their effects on bioactive compounds and physicochemical characteristics of collard greens. Twelve treatments were assessed in randomized blocks in a split-plot scheme, where the main plots received three types of soil amendments (preplanting incorporation of organic compost; gypsum; and organic compost + gypsum), and the subplots received four rates of topdress-applied sulfur $\left(0 ; 80 ; 160\right.$; and $240 \mathrm{~kg} \mathrm{ha}^{-1}$ of S). Flavonoid bioactive compounds, total antioxidant activity, and total phenolic compounds were evaluated. The physicochemical characteristics assessed were: reducing sugars, total sugars, sucrose, soluble solids, $\mathrm{pH}$, titratable acidity, fiber, protein, pigments (chlorophyll a, b, anthocyanins, and total carotenoids), and the relative chlorophyll index (SPAD index). The treatment whose soil was prepared with organic compost and a topdressing of sulfur from ammonium sulfate increased the flavonoid content in the collard plants. Gypsum application to soil increased the antioxidant activity in the collard leaves but, when combined with organic compost, it decreased the levels of phenolic compounds thereof. The rates of topdress-applied sulfur and the use of organic compost or gypsum in the soil, or the combination of both methods, did not affect the physicochemical characteristics and the pigments of commercial collard leaves. The use of organic compost combined with gypsum during soil preparation decreased the SPAD index in commercial collard leaves. The rates of topdress-applied sulfur showed no influence on the SPAD index in commercial collard leaves.

Keywords: Brassica oleracea L. var. acephala, organic fertilization, gypsum.
\end{abstract}

Estudou-se a utilização do enxofre, gesso e composto orgânico sobre compostos bioativos e características físico-químicas de couve-de-folha. Foram avaliados doze tratamentos, delineados em blocos casualizados em esquema de parcelas subdivididas, sendo três tipos de preparo de solo as parcelas (incorporação pré-plantio de composto orgânico; gesso agrícola e composto orgânico + gesso agrícola), e quatro doses de enxofre em cobertura as subparcelas $\left(0 ; 80 ; 160\right.$ e $\left.240 \mathrm{~kg} \mathrm{ha}^{-1} \mathrm{de} \mathrm{S}\right)$. Foram avaliados flavonoides, atividade antioxidante total e compostos fenólicos totais, características físico-químicas: açúcares redutores, açúcares totais, sacarose, sólidos solúveis, $\mathrm{pH}$, acidez titulável, fibras, proteína, pigmentos (clorofila a, b, antocianinas e carotenoides totais) e o índice relativo de clorofila (índice SPAD). O preparo de solo com composto orgânico associado ao enxofre via sulfato de amônio em cobertura aumenta os teores de flavonoides na couve-defolha. O gesso aplicado no preparo de solo aumenta a atividade antioxidante da couve-de-folha. Mas quando associado ao composto orgânico diminui os teores de compostos fenólicos contidos nessa hortaliça. A aplicação de doses de enxofre em cobertura, o preparo do solo com adubação orgânica, gessagem e a combinação das duas técnicas, não afetam as características físico-químicas e pigmentos presentes nas folhas comerciais de couve-de-folha. A utilização do composto orgânico mais gessagem no preparo de solo diminui o índice SPAD em folhas comerciais de couve-de-folha. O uso de doses de enxofre em cobertura não interfere no índice SPAD das folhas comerciais de couve-de-folha.

Palavras-chave: Brassica oleracea L. var. acephala, adubação orgânica, gesso. 


\section{INTRODUCTION}

Kale or collards (Brassica oleracea var. acephala) are a widely grown and consumed vegetable in the world. China is the world's main producer of kale, followed by India, Russia, South Korea, Ukraine, and Japan [1]. Kale and collards form a group of plants of the same species, i.e. Brassica oleracea, which includes cabbage (Brassica oleracea var. capitata), cauliflower (B. oleracea var. botritys), broccoli (B. oleracea var. italica), and others that differ from each other according to their botanical varieties [2].

Collard greens are a good source of calcium, potassium, magnesium, fiber, vitamin A, and vitamin $\mathrm{C}$, and have a low calorie value $[3,4,5]$. Carotenoids (lutein and beta-carotene), anthocyanins and chlorophylls present in their leaves reduce free radicals in the human body and help prevent some degenerative chronic diseases $[6,7]$.

Additionally, they are rich in nutrients and bioactive compounds [8]. In kale or collard cultivars, the content and amount of secondary metabolites varies significantly according to endogenous developmental factors, such as gene expression and protein modification, along with environmental conditions [9].

Sulfur is a component of the amino acids cysteine and methionine in plants. Deficiency of this nutrient reduces protein synthesis [10]. It plays an important role in the growth of Brassica plants, as this species requires from 70 to $80 \mathrm{~kg} \mathrm{ha}^{-1}$ thereof, while for most crops the range is from 15 to $50 \mathrm{~kg} \mathrm{ha}^{-1}[11,12]$. Previous studies on cauliflower identified sulfur as the fourth most accumulated nutrient in the plant, and the second in the seeds [13]. The same was found in broccoli seeds [14], thus showing the importance of this nutrient for the Brassica family.

The absorption of sulfur in the plant takes place in the form of sulfate-sulfur $\left(\mathrm{SO}_{4}{ }^{2-}\right)$, and its primary source in the soil derives from the decomposition of organic matter. However, gypsum application also contributes to the supply of sulfur and calcium in the form of calcium sulfate. In addition, gypsum can reduce aluminum toxicity in the soil and favor deep root growth, thus leading to greater water absorption and increased drought tolerance $[15,16]$.

Despite the importance of kale/collard greens in the human diet, there has been little research regarding this crop. In view of that, this study aims to evaluate the effects of sulfur, gypsum, and organic compost application on the contents of bioactive compounds and physicochemical characteristics of collard plants.

\section{MATERIAL AND METHODS}

Collard seedlings were grown in an area of typical dystrophic Red Latosol with sandy texture in the São Manuel Experimental Farm of the Faculty of Agronomic Sciences (FCA), Sao Paulo State University (UNESP), Botucatu Campus, located in the municipality of São Manuel (22 $46^{\prime}$ 'S; $\left.48^{\circ} 34^{\prime} \mathrm{W}\right)$, State of São Paulo, at $750 \mathrm{~m}$ altitude. The physicochemical analyses were carried out at the Laboratory of Fruit and Vegetable Post-Harvest of the FCA's Department of Horticulture.

The predominant climate of the municipality of São Manuel is Cfa, according to the Köppen classification, a temperate/mesothermal, humid subtropical climate with hot summers, with the warmest month averaging above $22^{\circ} \mathrm{C}[17]$.

The results of the soil chemical analysis at a $0-20 \mathrm{~cm}$ depth were: $\mathrm{pH}\left(\mathrm{CaCl}_{2}\right)=6.3 ; \mathrm{OM}=13 \mathrm{~g}$ $\mathrm{dm}^{-3} ; \mathrm{P}_{\text {resin }}=82 \mathrm{mg} \mathrm{dm}{ }^{-3} ; \mathrm{H}+\mathrm{Al}=12 \mathrm{mmol}_{\mathrm{c}} \mathrm{dm}^{-3} ; \mathrm{K}=1.2 \mathrm{mmol}_{\mathrm{c}} \mathrm{dm}^{-3} ; \mathrm{Ca}=28 \mathrm{mmol}_{\mathrm{c}} \mathrm{dm}^{-3} ; \mathrm{Mg}$ $=8 \mathrm{mmol}_{\mathrm{c}} \mathrm{dm}^{-3} ; \mathrm{S}=3 \mathrm{mg} \mathrm{dm}^{-3}, \mathrm{SB}=37 \mathrm{mmol}_{\mathrm{c}} \mathrm{dm}^{-3} ; \mathrm{CEC}=49 \mathrm{mmol}_{\mathrm{c}} \mathrm{dm}^{-3} ;$ and $\mathrm{V} \%=76$.

Twelve treatments were evaluated in a split plot design, with three types of soil amendment applied to the main plots, and four topdress sulfur rates applied to the subplots. The experiment was arranged in a randomized block design with four replications, with 18 plants per plot distributed in three planting rows, the net plot area being the four central plants, from which leaves were collected.

Three methods of soil amendment were implemented: pre-planting incorporation of Visafértil ${ }^{\circledR}$ organic compost $\left(30 \mathrm{t} \mathrm{ha}^{-1}\right)$, containing $120 \mathrm{~kg} \mathrm{ha}^{-1}$ of $\mathrm{S}$; gypsum $\left(1.2 \mathrm{tha}^{-1}\right)$, containing $156 \mathrm{~kg} \mathrm{ha}^{-}$ ${ }^{1}$ of S; and organic compost $\left(30 \mathrm{tha}^{-1}\right)+$ gypsum $\left(1.2 \mathrm{tha}^{-1}\right)$, containing $276 \mathrm{~kg} \mathrm{ha}^{-1}$ of S. All plots received $2 \mathrm{t} \mathrm{ha}^{-1}$ of the 04-14-08 formulated fertilizer for the soil pre-planting treatment. The rates were based on the low sulfur content found in the soil chemical analysis. The treatments and fertilizers were incorporated into the soil with a bed shaper rotary tiller. 
The chemical analysis of Visafértil ${ }^{\circledR}$, carried out at the FCA's Laboratory of Soils and Environmental Resources, yielded values expressed in percentage, in the natural state, and indicated the following contents: $0.7 \mathrm{~N} ; 1.0 \mathrm{P}_{2} \mathrm{O}_{5} ; 0.7 \mathrm{~K}_{2} \mathrm{O} ; 6.8 \mathrm{Ca} ; 0.4 \mathrm{Mg} ; 0.4 \mathrm{~S} ; 24$ OM-Total; and $13 \mathrm{C}$-Total; and in $\mathrm{mg} \mathrm{kg}^{-1}: 2558 \mathrm{Na} ; 67 \mathrm{Cu} ; 17316 \mathrm{Fe} ; 577 \mathrm{Mn} ; 97 \mathrm{Zn} ; 19.1 \mathrm{of} \mathrm{C} / \mathrm{N}$ ratio; and $\mathrm{pH}=6.0$.

Based on Trani and Raij's (1996) [18] recommendations for topdressing fertilizers for 'butter collard', the total sulfur rates applied were $0 ; 80 ; 160$; and $240 \mathrm{~kg} \mathrm{ha}^{-1}$ of $\mathrm{S}$, corresponding to 0 ; 400; 800; and $1200 \mathrm{~kg} \mathrm{ha}^{-1}$ of ammonium sulfate fertilizer. To standardize the nitrogen (N) topdressing at $240 \mathrm{~kg} \mathrm{ha}^{-1} \mathrm{~N}$, the amounts of $540,356,179$, and $0 \mathrm{~kg} \mathrm{ha}^{-1}$ of urea were used. The total rates of topdressing fertilizers were divided into six applications, with an interval of 14 days between them.

Topdressing fertilizers were applied onto the soil surface around each plant. The first topdressing, as planned for the treatments, was applied at 15 days after transplanting (DAT) the seedlings to the field, then repeated every 14 days. Potassium chloride $\left(20 \mathrm{~kg} \mathrm{ha}^{-1} \mathrm{~K}_{2} \mathrm{O}\right.$ in each application) was applied from the third topdressing onwards. Sprinkler irrigation was performed with $3 \mathrm{~mm} \mathrm{day}^{-1}$, and crop management followed recommendations by Filgueira (2008) [2] and Trani et al. (2015) [19].

Hi-Crop ${ }^{\circledR}$ hybrid collard seeds were sown on 162-cell black polypropylene trays, one seed per cell, filled with Carolina Soil ${ }^{\circledR}$ substrate, on July 29, 2016. At 27 days after sowing, the seedlings were transplanted to permanent beds spaced at $0.50 \mathrm{~m}$ between row sand $1.60 \mathrm{~m}$ between plants, following the quincunx system and with three rows per vegetable patch, which resulted in 12,500 plants per hectare.

The first harvest of collard leaves took place on 09/30/2016, then repeated every 10 days. At the sixth harvest (88 DAT), three samples of commercial leaves were collected at an intermediate height in the collard plants from each subplot. The leaves were taken to the laboratory, washed with tap water, and left to dry naturally for later assessment of their flavonoid bioactive compounds [20, 21] expressed in mg quercetin $100 \mathrm{~g}^{-1}$; total antioxidant activity [22] expressed in percentage; and total phenolic compounds [23] in $\mathrm{mg}$ gallic acid $100 \mathrm{~g}^{-1}$. Furthermore, the following physicochemical characteristics were evaluated: reducing sugars; total sugars; sucrose [24, 25] expressed in percentage; soluble solids [26] in ${ }^{\circ}$ Brix; $\mathrm{pH}$ [27], titratable acidity [27] in g citric acid $100 \mathrm{~g}^{-1}$; fiber [26] in percentage; protein [27] in percentage; chlorophyll $a$, chlorophyll $b$, anthocyanins, and carotenoids [28] expressed in $\mathrm{mg} 100 \mathrm{~g}^{-1}$; and relative chlorophyll index (SPAD index).

The obtained data were analyzed by analysis of variance, and significance was verified by the $F$ test. The means of the soil amendment treatments were compared by the Tukey's test at a 0.05 significance level. The sulfur rates were examined by regression analysis. The software application used to analyze the data was Sisvar [29].

\section{RESULTS AND DISCUSSION}

The analysis of bioactive compounds showed a significant influence of the soil amendment factor on total antioxidant activity and total phenolic compound contents, but the $\mathrm{S}$ rates had no influence on the variables under study (Table 1). However, the results showed a significant interaction between the factors studied for flavonoid contents.

The highest antioxidant activity was found for the soil amendments organic compost +gypsum (54.56\%) and gypsum alone $(50.10 \%)$, whereas the lowest was observed for organic compost alone (38.29\%). The addition of sulfur and calcium via gypsum, coupled with the content already present in the organic compost, may have directly influenced the increase in the antioxidant activity. Armesto et al. (2019) [30] reported high antioxidant activity in Galega collard (Brassica oleracea var. acephala cv. Galega), with $84.79 \%$. Rigueira et al. (2016) [31] observed high antioxidant activity in leaf and stem samples of 'butter collard' (Brassica oleracea L. var. acephala) grown in an organic system in comparison with plants grown in conventional systems. 
Table 1. Flavonoid contents (mg quercetin $100 \mathrm{~g}^{-1}$ ), total antioxidant activity (\%), and total phenolic compounds ( $m g$ gallic acid $100 \mathrm{~g}^{-1}$ ) in commercial collards grown in different soil amendments and four rates of topdress-applied sulfur. São Manuel-SP, 2016.

\begin{tabular}{|c|c|c|c|}
\hline Soil amendment & $\begin{array}{c}\text { Flavonoids }(\mathbf{m g} \\
\left.\text { quercetin } 100 \mathrm{~g}^{-1}\right)\end{array}$ & $\begin{array}{c}\text { Total } \\
\text { antioxidant } \\
\text { activity }(\%)\end{array}$ & $\begin{array}{c}\text { Total phenolic } \\
\text { compounds(mg gallic } \\
\left.\text { acid100 } \mathrm{g}^{-1}\right)\end{array}$ \\
\hline $\begin{array}{l}\text { Organic compost } \\
\text { (O.C.) }\end{array}$ & 24.90 & $38.29 \mathrm{~b}$ & $326.0 \mathrm{a}$ \\
\hline Gypsum (G) & 28.94 & $50.10 \mathrm{a}$ & $322.2 \mathrm{a}$ \\
\hline O.C. + G & 24.21 & $54.56 \mathrm{a}$ & $288.1 \mathrm{~b}$ \\
\hline $\begin{array}{l}\text { S rates } \\
\left(\mathrm{kg} \mathrm{ha}^{-1}\right)\end{array}$ & $\begin{array}{l}\text { Flavonoids }(\mathbf{m g} \\
\left.\text { quercetin } \mathbf{1 0 0 g}^{-1}\right)\end{array}$ & $\begin{array}{c}\text { Total antioxidant } \\
\text { activity }(\%)\end{array}$ & $\begin{array}{l}\text { Total phenolic } \\
\text { compounds (mg } \\
\text { gallic acid100 g-1) }\end{array}$ \\
\hline $\mathbf{0}$ & 25.92 & 41.11 & 308.5 \\
\hline 80 & 26.85 & 45.11 & 320.9 \\
\hline 160 & 23.56 & 51.08 & 298.8 \\
\hline 240 & 27.77 & 53.30 & 320.2 \\
\hline Overall mean & 26.03 & 47.65 & 312.1 \\
\hline C.V.1 (\%) & 18.8 & 16.0 & 6.9 \\
\hline C.V.2 (\%) & 22.7 & 23.6 & 13.3 \\
\hline F(soil.a) & $0.07^{\mathrm{ns}}$ & $0.002^{* *}$ & $0.005^{* *}$ \\
\hline $\mathbf{F}(\mathbf{S})$ & $0.36^{\mathrm{ns}}$ & $0.052^{\mathrm{ns}}$ & $0.523^{\mathrm{ns}}$ \\
\hline F(soil.a x S) & $0.01^{*}$ & $0.119^{\text {ns }}$ & $0.674^{\text {ns }}$ \\
\hline
\end{tabular}

${ }^{\mathrm{ns}}$ not significant, $*$ significant by the $\mathrm{F}$ test at the 0.05 significance level, and $* *$ significant by the $\mathrm{F}$ test at the 0.01 significance level.

${ }^{1}$ Means followed by the same letter in the column do not differ statistically by the Tukey's test at the 0.05 significance level.

The highest contents of phenolic compounds were found for the soil amendments with organic compost alone (326 mg of gallic acid $100 \mathrm{~g}^{-1}$ ) and gypsum alone (322.2 mg of gallic acid $100 \mathrm{~g}^{-1}$ ). However, the soil prepared with organic compost + gypsum resulted in the lowest content of phenolic compounds (288.1 mg of gallic acid $100 \mathrm{~g}^{-1}$ ). Rigueira et al. (2016) [31] found no significant difference between total phenolics in collard leaves grown in conventional and organic systems, with mean content values between 173 and $244 \mathrm{mg}$ gallic acid $100 \mathrm{~g}^{-1}$. Most of the total antioxidant activity of Brassica spp. is associated with phenolic compounds, especially flavonoids, which provide protection against free radicals [30]. Silva et al. (2010) [32] reviewed the available literature on methods for evaluating phenolic compounds and carotenoids and concluded that the continued intake of foods rich in these compounds is associated with the prevention of several degenerative diseases.

Figure 1 shows that the flavonoid content of collard leaves increased with the use of organic compost and the rate of $240 \mathrm{~kg} \mathrm{ha}^{-1}$ of $\mathrm{S}$ topdressing. Collard plants grown in soil with gypsum showed a linear decrease in the flavonoid content with the increase of $\mathrm{S}$ rates. No influence of the soil amendment with organic compost + gypsum and S rates was observed on the flavonoid contents in collard plants. As the environmental conditions and the organic compost rates were the same, the presence of nitrogen in the ammonium sulfate associated with macronutrients $\mathrm{P}, \mathrm{K}$ and $\mathrm{Mg}$ in the organic compound may have favored the production of flavonoids in collards, as the presence of calcium sulfate (gypsum) associated with ammonium sulfate did not favor the production of flavonoids [58, 59]. De Pascale (2007) [33] points out that sulfur is essential in the biosynthesis of secondary metabolites with high nutritional value that normally accumulate in Brassica species, which was observed here only in the treatment with organic compost. 


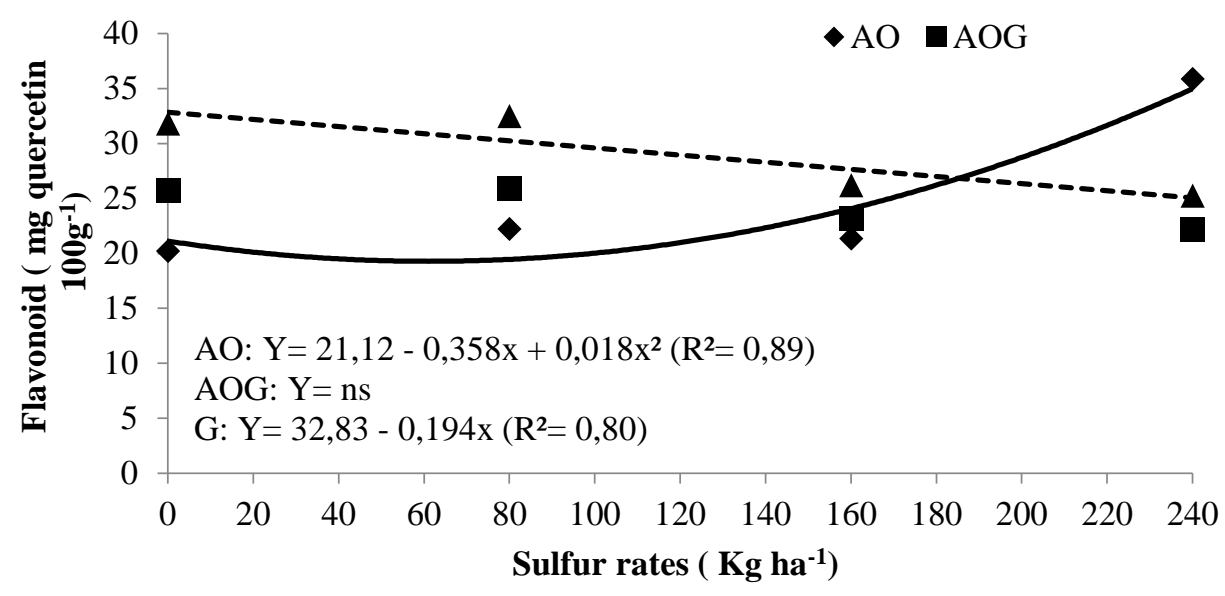

Figure 1: Flavonoid contents (mg quercetin $100 \mathrm{~g}^{-1}$ ) in commercial collard grown in different soil amendments and four rates of topdress-applied sulfur. São Manuel-SP, 2016.

The factors soil amendments and topdress sulfur rates were not significant for reducing sugars, soluble solids, $\mathrm{pH}$, titratable acidity, fiber, and protein, neither was the interaction between these factors significant by the $\mathrm{F}$ test at a 0.05 significance level (Table 2). The polynomial regression analysis also found no significant effect of $\mathrm{S}$ rates on the characteristics evaluated.

There were no significant changes in the percentage of reducing sugars, with an overall mean of $1.74 \%$ (Table 2). Due to the lack of sucrose in the collard leaves analyzed, the total sugar content was considered equal to that of the reducing sugar content. In this case, the analysis took into account only the monosaccharides, glucose and fructose present in the leaves. These values can be considered low when compared with the reducing sugar content of $4 \%$ in minimally processed cabbage [34] and $3.45 \%$ to $3.86 \%$ in cauliflower inflorescence at rates of topdress-applied potassium [35]. Chitarra and Chitarra (2006) [36] state that the variation in the content of these sugars in vegetables ranges between $2 \%$ and $5 \%$, hence the values in collards were lower than those in most vegetables.

Table 2: Reducing sugars (RS), soluble solids (SS), pH, titratable acidity (TA), fiber, and protein in commercial collards grown in different soil amendments and four rates of topdress-applied sulfur. São Manuel-SP, 2016.

\begin{tabular}{|c|c|c|c|c|c|c|}
\hline Soil amendment & $\begin{array}{l}\text { RS } \\
(\%)\end{array}$ & $\begin{array}{c}\text { SS } \\
\left({ }^{\circ} \text { Brix }\right)\end{array}$ & pH & $\begin{array}{l}\text { TA } \\
(\%)\end{array}$ & $\begin{array}{c}\text { Fiber } \\
(\%)\end{array}$ & $\begin{array}{c}\text { Protein } \\
(\%)\end{array}$ \\
\hline Organic compost (O.C.) & 1.80 & 9.19 & 6.23 & 0.25 & 1.87 & 2.78 \\
\hline Gypsum $(\mathbf{G})$ & 1.81 & 9.16 & 6.22 & 0.25 & 1.99 & 2.83 \\
\hline O.C. + G & 1.61 & 9.50 & 6.27 & 0.25 & 1.93 & 2.84 \\
\hline $\begin{array}{l}\text { S rates } \\
\left(\text { kg ha }^{-1}\right)\end{array}$ & $\begin{array}{l}\text { RS } \\
(\%)\end{array}$ & $\begin{array}{c}\text { SS } \\
\left({ }^{\circ} \text { Brix }\right)\end{array}$ & pH & $\begin{array}{l}\text { TA } \\
(\%)\end{array}$ & $\begin{array}{c}\text { Fiber } \\
(\%)\end{array}$ & $\begin{array}{c}\text { Protein } \\
(\%)\end{array}$ \\
\hline 0 & 1.70 & 8.92 & 6.25 & 0.24 & 2.01 & 2.73 \\
\hline 80 & 1.72 & 9.21 & 6.25 & 0.25 & 2.06 & 2.81 \\
\hline 160 & 1.80 & 9.58 & 6.23 & 0.27 & 1.73 & 2.81 \\
\hline 240 & 1.75 & 9.42 & 6.22 & 0.24 & 1.91 & 2.92 \\
\hline Overall mean & 1.74 & 9.28 & 6.24 & 0.25 & 1.93 & 2.82 \\
\hline C.V.1 (\%) & 16.77 & 9.26 & 2.36 & 28.35 & 16.38 & 9.47 \\
\hline C.V.2 (\%) & 15.93 & 9.96 & 1.95 & 21.34 & 16.65 & 10.17 \\
\hline F(soil.a) & $2.35^{\mathrm{ns}}$ & $0.78^{\mathrm{ns}}$ & $0.43^{\mathrm{ns}}$ & $0.06^{\mathrm{ns}}$ & $0.60^{\mathrm{ns}}$ & $0.24^{\mathrm{ns}}$ \\
\hline $\mathbf{F}(\mathbf{S})$ & $0.30^{\mathrm{ns}}$ & $1.16^{\mathrm{ns}}$ & $0.30^{\mathrm{ns}}$ & $0.51^{\mathrm{ns}}$ & $2.43^{\mathrm{ns}}$ & $0.88^{\mathrm{ns}}$ \\
\hline F(soil.a x S) & $1.50^{\mathrm{ns}}$ & $0.64^{\mathrm{ns}}$ & $0.92^{\mathrm{ns}}$ & $1.03^{\mathrm{ns}}$ & $1.38^{\mathrm{ns}}$ & $0.88^{\mathrm{ns}}$ \\
\hline
\end{tabular}

${ }^{\mathrm{ns}}$ not significant at by the $\mathrm{F}$ test at a 0.05 significance level. 
The different soil amendments and topdress sulfur rates had no influence on soluble solids contents of commercial collards, with an overall mean of $9.28^{\circ}$ Brix (Table 2). Lower values were found by Sanches et al. (2016) [37] in curly 'butter collard' (7.8 'Brix), by Salata et al. (2014) [34] in minimally processed cabbage immediately after harvest (5.65 ${ }^{\circ}$ Brix), and by Godoy et al. (2012) [35] in cauliflower $\left(6.58^{\circ} \mathrm{Brix}\right)$. This trait can be influenced by various production factors such as genetic material, soil type, climate, and crop cultural practices.

Soil amendments and topdress sulfur rates caused no significant changes in $\mathrm{pH}$ and titratable acidity in the collard leaves (Table 2), with an overall mean of $\mathrm{pH}=6.24$ and titratable acidity $=$ $0.25 \%$. Sanches et al. (2016) [37] reported lower pH (5.20) and higher titratable acidity $(0.31 \%)$ values for curly 'butter collard', which is an evidence of consistency in the results, i.e., higher acidity with lower $\mathrm{pH}$. Pereira et al. (2015) [38] evaluated collards produced in an organic system and reported $\mathrm{pH}$ of 5.6 and titratable acidity of $0.20 \%$. Acidity is known to quantify the presence of organic acids in vegetables, and acidity is generally low in vegetables.

The mean fiber content was $1.93 \%$ (Table 2), with no influence from the factors soil preparation and topdress sulfur rates. In the vegetable nutrient composition table organized by Luengo et al. (2011) [39], 'butter collard' appears with 1.3\% of fibers. However, the Brazilian Food Composition Table presents a higher content thereof for raw collard leaves, with $3.1 \%$ of fibers [4].

The mean percentage of protein $(2.82 \%)$ in collard leaves was not significantly influenced by the treatments (Table 2). This result is very close to the data presented in the Brazilian Food Composition Table, which reports protein values of $2.9 \%$ for raw collard leaves [4] and $2.83 \%$ for braised collard leaves [3]. These protein contents compared with those of vegetables such as zucchini ( 0.6 to $1.1 \%)$, lettuce ( 0.6 to $1.7 \%$ ), carrot (1.3\%), cauliflower (1.9\%), bell pepper (1.0 to $1.2 \%)$, cabbage (0.9 to $1.9 \%)$, and tomato $(1.1 \%)$ show that collard greens have a significant value, behind only another Brassica: broccoli (3.6\%) [4].

The applied soil amendments and sulfur rates did not affect the levels of chlorophyll $a$ and $b$, carotenoids, or anthocyanins (Table 3). Chlorophyll $a$ and $b$ contents had an overall mean of 10.06 mg $100 \mathrm{~g}^{-1}$ and $3.48 \mathrm{mg} 100 \mathrm{~g}^{-1}$, respectively (Table 3). Von Elbe (2000) [40] observed that chlorophylls $a$ and $b$ have a 3:1 ratio in nature, which is very close to the 2.9:1 ratio found in the present study.

The concentrations of chlorophyll $a$ and $b$ (Table 3) were lower than those found by Padula et al. (2006) [41], in broccoli leaves, of $15.50 \mathrm{mg} 100 \mathrm{~g} \mathrm{~g}^{-1}$ chlorophyll $a$ and $9.16 \mathrm{mg} 100 \mathrm{~g} \mathrm{~g}^{-1}$ chlorophyll $b$.

As can be seen in Table 3, the use of sulfur combined with the different soil amendments had no significant effect on the carotenoid and anthocyanin contents in collard leaves, with means of 2.96 and $0.70 \mathrm{mg} 100 \mathrm{~g}^{-1}$, respectively. This study found a chlorophyll:carotenoid ratio of 4.6:1, which is close to the 5:1 ratio reported by Von Elbe and Schwartz (1996) [43]. Carvalho et al. (2006) [44] mentioned that the body converts carotenoids into vitamin A, and these natural pigments can be found in yellow-orange and dark green leafy vegetables, such as the collard species in this study. Rodriguez-Amaya, Kimura and Amaya-Farfan (2008) [45] found $3.40 \mathrm{mg} 100 \mathrm{~g}^{-1}$ of total

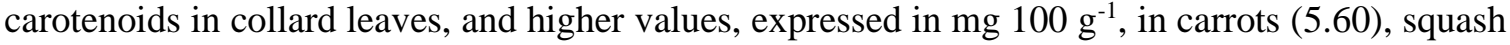
(9.90), watercress (10.70), common chicory (12.0), and arugula (13.30).

Taiz and Zeiger (2009) [42] discuss that carotenoids - yellow or orange colored accessory pigments often hidden by chlorophyll - can provide the photosynthetic system with photoprotection against singlet oxygen $\left({ }^{1} \mathrm{O}_{2}{ }^{*}\right)$ toxicity, which can destroy compounds such as lipids. In this sense, Wahid (2007) [46] reported that these pigments prevent oxidative damage caused by stress. Anthocyanins, which belong to the flavonoid group, are characterized by their antioxidant, antiinflammatory and anticarcinogenic properties [47, 44].

The analysis of variance (Table 3) showed no significant effect of topdress sulfur rates on the chlorophyll index, which ranged from 53.98 to 58.65 SPAD units, with an overall mean of 56.2 SPAD units. Conversely, significantly higher indices were found for the use of organic compost alone compared with the application of organic compost +gypsum in the soil preparation before transplantation (Table 3). 
Table 3: Contents of chlorophyll a and b, carotenoids, anthocyanins, and the SPAD index in commercial collard leaves grown in different soil amendments and four rates of topdress-applied sulfur. São ManuelSP, 2016.

\begin{tabular}{|c|c|c|c|c|c|}
\hline \multirow{3}{*}{$\begin{array}{l}\text { Soil } \\
\text { amendment }\end{array}$} & \multicolumn{2}{|c|}{ Chlorophyll } & \multirow{2}{*}{ carotenoids } & \multirow[t]{2}{*}{ anthocyanins } & \multirow{3}{*}{$\begin{array}{l}\text { SPAD } \\
\text { (unid.) }\end{array}$} \\
\hline & $a$ & $b$ & & & \\
\hline & \multicolumn{2}{|c|}{$\left(\mathrm{mg} \mathrm{100} \mathrm{g} \mathrm{g}^{-1}\right)$} & \multicolumn{2}{|c|}{$\left(\mathrm{mg} 100 \mathrm{~g}^{-1}\right)$} & \\
\hline $\begin{array}{l}\text { Organic } \\
\text { compost } \\
\text { (O.C.) }\end{array}$ & 9.55 & 3.37 & 2.80 & 0.69 & $57.3 \mathrm{a}^{1}$ \\
\hline Gypsum (G) & 9.66 & 3.51 & 2.93 & 0.75 & $56.3 \mathrm{ab}$ \\
\hline O.C. + G & 10.96 & 3.55 & 3.14 & 0.65 & $54.9 \mathrm{~b}$ \\
\hline \multirow{3}{*}{$\begin{array}{l}\text { S rates } \\
\left(\text { kg ha }^{-1}\right)\end{array}$} & \multicolumn{2}{|c|}{ Chlorophyll } & carotenoids & anthocyanins & SPAD \\
\hline & $a$ & $\boldsymbol{b}$ & & & \\
\hline & \multicolumn{2}{|c|}{$\left(\mathrm{mg} \mathrm{100g^{-1 } )}\right.$} & \multicolumn{2}{|c|}{$\left(\operatorname{mg~100g^{-1})}\right.$} & (unid.) \\
\hline $\mathbf{0}$ & 10.04 & 3.51 & 2.91 & 0.63 & 55.2 \\
\hline 80 & 9.66 & 3.47 & 2.87 & 0.70 & 56.8 \\
\hline 160 & 10.30 & 3.66 & 3.07 & 0.70 & 56.3 \\
\hline 240 & 10.23 & 3.27 & 2.97 & 0.76 & 56.3 \\
\hline Overall mean & 10.06 & 3.48 & 2.96 & 0.70 & 56.2 \\
\hline C.V.1 (\%) & 35.45 & 25.77 & 24.95 & 20.82 & 3.09 \\
\hline C.V.2 (\%) & 31.29 & 24.03 & 21.66 & 45.27 & 6.05 \\
\hline F(soil.a) & $0.77^{\mathrm{ns}}$ & $0.17^{\mathrm{ns}}$ & $0.86^{\mathrm{ns}}$ & $1.80^{\mathrm{ns}}$ & $7.94 * *$ \\
\hline $\mathbf{F}(\mathbf{S})$ & $0.10^{\mathrm{ns}}$ & $0.46^{\mathrm{ns}}$ & $0.22^{\mathrm{ns}}$ & $0.37^{\mathrm{ns}}$ & $0.48^{\mathrm{ns}}$ \\
\hline F(soil.a x S) & $1.12^{\mathrm{ns}}$ & $1.82^{\mathrm{ns}}$ & $1.49^{\mathrm{ns}}$ & $0.27^{\mathrm{ns}}$ & $0.54^{\mathrm{ns}}$ \\
\hline
\end{tabular}

${ }_{\mathrm{ns}}$ not significant, $* *$ significant by $\mathrm{F}$ test at the 0.01 significance level.

${ }^{1}$ Means followed by the same letter in the column do not differ statistically by the Tukey's test at the 0.05 significance level.

The high concentration of $\mathrm{Ca}^{2+}$ in the soil $\left(28\right.$ mmolc $\left.\mathrm{dm}^{-3}\right)$, coupled with the use of gypsum, organic compost, topdress-applied potassium, and low CEC, may have displaced $\mathrm{Mg}^{2+}$ in the exchange sites, which preferably leached in the soil in the form of $\mathrm{Mg}^{2+}$ ions or formed ionic pairs with $\mathrm{SO}_{4}{ }^{2-}[48,49,50,51]$. Lower Mg levels in collards may result in less intense green leaves, thus reducing the SPAD index values. However, no symptoms of Mg deficiency were observed for the leaves in all treatments.

Soares et al. (2017) [52] found that topdress-applied sulfur in the form of ammonium sulfate increased green color intensity in arugula leaves, which, according to the authors, favored the product quality, attracting consumers looking for greener and more vigorous leaves. Sediyama et al. (2009) [53] observed a linear increase in the relative chlorophyll index (SPAD) in okra leaves with increased rates of swine biofertilizer.

Henz and Mattos (2008) [54] point out that food and nutrition professionals recommend leafy vegetables with brighter and greener color. However, in this study, no visible differences were found in leaf color as a function of S rates. Moreover, all the plants in the experiment received S directly or indirectly at planting, either via organic compost and/or gypsum - what varied was the amount of topdressing.

Moreira and Vidigal (2009) [55] reported 53.5 SPAD units for cabbage hybrid Shutoku fertilized with $278 \mathrm{~kg} \mathrm{ha}^{-1} \mathrm{~N}$, rate that led to the highest fresh biomass of cabbage heads. Increased applications of nitrogen and organic fertilizers in zucchini, okra and tomatoes resulted in increased the chlorophyll content and/or the SPAD indices in the leaves thereof $[53,56,57]$. Consequently, $\mathrm{N}$ influences leaf color and the SPAD index. Nevertheless, all the treatments received the same nitrogen topdressing rate. 


\section{CONCLUSIONS}

The application of organic compost alone and gypsum alone during soil preparation provides the highest content of total phenolic compounds in collard greens.

The application of organic compost combined with a topdressing of sulfur from ammonium sulfate during soil preparation increases the flavonoid content in collard greens.

The application of gypsum during soil preparation increases the antioxidant activity of collards greens. However, when with organic compost, the content of phenolic compounds decreases.

Soil preparations with rates of topdress-applied sulfur, and with compost or gypsum, or the combination of the two methods, have no effect on the physicochemical characteristics and the pigment content of commercial collard greens.

The application of organic compost combined with gypsum during soil preparation decreases the SPAD index in commercial collard leaves. The SPAD indices reaches the highest values when organic compost alone is applied to the soil.

Rates of topdress-applied sulfur have no effect on the relative chlorophyll index (SPAD) in commercial collard greens.

\section{REFERENCES}

1. Food and Agriculture Organization of the Unites Nations. FAOSTAT - 2014. [Internet]. [accessed 16th May 2017] Available from: http://www.fao.org/faostat/en/\#data/QC.

2. Filgueira FAR. Brassicáceas: couves e plantas relacionadas. In: Filgueira, FAR. Novo manual de olericultura: agrotecnologia moderna na produção e comercialização de hortaliças. 3rd rev ed. Viçosa: UFV; 2008. p. 279-299.

3. Pacheco M. Tabela de equivalentes, medidas caseiras e composição química dos alimentos. 2nd ed. Rio de Janeiro: Rubio; 2011. 669 p.

4. Núcleo de Estudos e Pesquisas em Alimentação - NEPA. Tabela de composição dos alimentos -TACO. Universidade Estadual de Campinas. 4th rev. ed. Campinas: UNICAMP, 2011. $161 \mathrm{p}$.

5. Sikora E, Bodziarczyk I. Composition and antioxidant activity of kale (Brassica oleracea L. var. acephala) raw and cooked. Acta Sci Pol Technol Aliment. 2012;11(3):239-248.

6. Lefsrud M, Kopsell DA, Wenzel A, Sheehan J. Chances in kale (Brassica oleracea L. var. acephala) carotenoid and chlorophyll pigment concentrations during leaf ontogeny. Sci Horticult. 2007;112(2):136-141, doi: 10.1016/j.scienta.2006.12.026.

7. Ligor M, Trziszka T, Buszewski B. Study of antioxidant activity of biologically active compounds isolated from green vegetables by coupled analytical techniques. Food Anal Methods. 2013;6(2):630-636, doi: 10.1007/s12161-012-9367-9.

8. Baenas N, Moreno DA, Garcia-Viguera C. Selecting sprouts of Brassicaceae for optimum phytochemical composition. J Agri Food Chem. 2012;60(45):11409-11420, doi: 10.1021/jf302863c.

9. Jeon J, Kim JK, Kim H, Kim YJ, Park YJ, Kim SJ, et al. Transcriptome analysis and metabolic profiling of green and red kale (Brassica oleracea var. acephala) seedlings. Food Chem. 2018;(241):7-13, doi: 10.1016/j.foodchem.2017.08.067.

10. Cantarella H, Montezano ZF. Nitrogênio e enxofre. In: Prochnow LI, Casarin V, Stipp SR, editors. Boas práticas para uso eficiente de fertilizantes: nutrientes. Piracicaba: IPNI-Brasil; 2010. p. 5-46.

11. Vitti GC, Heinrichs R. Formas tradicionais e alternativas de obtenção e utilização do nitrogênio e do enxofre: uma visão holística. In: Yamada T, Stipp SR, Vitti, GC. Nitrogênio e enxofre na agricultura brasileira. Piracicaba: IPNI Brasil; 2007. p. 109-160.

12. Alvarez-Venegas VH, Roscoe R, Kurihara CH, Pereira NF. Enxofre. In: Novais RF, Alvarez-Venegas VH, Barros NF, Fontes RLF, Cantarutti RB, Neves JCL, editors. Fertilidade do solo. Viçosa: Sociedade Brasileira de Ciência do Solo; 2007. p. 595-646.

13. Cardoso AII, Claudio MTR, Nakada-Freitas PG, Magro FO, Tavares AEB. Phosphate fertilization over the accumulation of macronutrients in cauliflower seed production. Hortic Bras. 2016;34(2):196-201, doi: 10.1590/S0102-053620160000200008.

14. Magro FO, Cardoso AII, Fernandes DM. Acúmulo de nutrientes em sementes de brócolis em função de doses de composto orgânico. Cultivo Saber. 2009;2(4):49-57.

15. van Raij B . Gesso na agricultura. Informações Agronômicas [Internet]. [2008; cited 2017 May 19]; 122. Available from: http://www.ipni.net/publication/iabrasil.nsf/0/B85CBF8A11ADF43E83257A90007E3924/\$FILE/Page26-27-122.pdf. 
16. Raij B van. Fertilidade do solo e manejo de nutrientes. Piracicaba: International Plant Nutrition Institute; 2011. $420 \mathrm{p}$.

17. Cunha AR da, Martins D. Classificação climática para os municípios de Botucatu e São Manuel, SP. Irriga. 2009;14(1):1-11, doi: 10.15809/irriga.2009v014n1p1-11.

18. Trani PE, Raij B van. Hortaliças. In: Raij B van, Cantarella H, Quaggio JA, Furlani AMC, editors. Recomendações de adubação e calagem para o Estado de São Paulo. 2nd ed. Campinas: Instituto Agronômico; 1996. (Boletim IAC; n. 100). p. 155-186.

19. Trani PE, Tivelli SW, Blat SF, Prela-Pantano A, Teixeira EP, Araújo HS et al. Couve de folha: do plantio à pós-colheita. [Internet]. Campinas: Instituto Agronômico, 2015. 36 p. Available from: http://www.iac.sp.gov.br/publicacoes/publicacoes_online/pdf/BoletimTecnico214.pdf. [accessed 18th May 2017]. (Boletim Tecnico IAC; n. 214).

20. Santos MD, Blatt CTT. Teor de flavonoides e fenóis totais em folhas de Pyrostegia venusta Miers. de mata e de cerrado. Braz J Bot. 1998;21(2):135-140, doi: 10.1590/S0100-84041998000200004.

21. Awad MM, Jager A, Westing LM. Flavonoid and chlorogenic acid levels in apple fruit: characterisation of variation. Sci Horticult. 2000 Mar;83 (3-4):249-263.

22. Mensor LL, Menezes FS, Leitão GG, Reis AS, Santos TC, Coube CS, et al. Screening of Brazilian plant extracts for antioxidant activity by the use of DPPH free radical method. Phyther Res. 2001;15(2):127130.

23. Singleton VL, Orthofer R, Lamuela-Raventós RM. Analysis of total phenols and other oxidation substrates and antioxidants by means of folin-ciocalteu reagent. Methods Enzymol. 1999;299(1974):152178, doi: 0.1016/S0076-6879(99)99017-1.

24. Nelson N. A photometric adaptation of Somogy method for the determination of Glucose. J Biol Chem. 1944; $153: 375-380$.

25. Somogyi M. Determination of blood sugar. J Biol Chem. 1945;(160):69-73.

26. Association of Official Analytical Chemistry. Official methods of analysis of the association of official analytical chemistry. 18th ed. Washington: AOAC; 2005.1015 p.

27. Brasil. Ministério da Saúde. Instituto Adolfo Lutz. Métodos físicos e químicos para análise de alimentos. 4. ed. Brasília (DF): Ministério da Saúde; 2008. 1020 p.

28. Sims DA, Gamon JA. Relationships between leaf pigment content and spectral reflectance across a wide range of species, leaf structures and developmental stages. Remote Sens Environ. 2002;81:337-354, doi: 10.1016/S0034-4257(02)00010-X.

29. Ferreira DF. Sisvar: Sistema de análise de variância. Version 5. 3. Lavras: UFLA; 2010.

30. Armesto J, Gómez-limia L, Carballo J, Martínez S. Effects of different cooking methods on the antioxidant capacity and flavonoid, organic acid and mineral contentes of Galega Kale (Brassica oleracea var. acephala cv. Galega). Int J Food Sci Nut. 2019;70(2):136-149, doi: 10.1080/09637486.2018.1482530.

31. Rigueira GDJ, Bandeira AVM, Chagas CGO, Milagres RCR de M. Atividade antioxidante e teor de fenólicos em couve-manteiga (Brassica oleracea L. var. acephala) submetida a diferentes sistemas de cultivo e métodos de preparo. Semin Ciên Biol Saúde. 2016;37(2):3-12, doi: 10.5433/16790367.2016v37n2p3.

32. Silva MLC, Costa RS, Santana A dos S, Koblitz MGB. Compostos fenólicos, carotenóides e atividade antioxidante em produtos vegetais. Semin Ciên Agr. 2010;31(3):669-682, doi: 10.5433/16790359.2010v31n3p669.

33. De Pascale S, Maggio A, Pernice R, Fogliano V, Barbieri G. Sulphur fertilization may improve the nutritional value of Brassica rapa L. subsp. sylvestris. Eur J Agron. 2007;26(4):418-424, doi: 10.1016/j.eja.2006.12.009.

34. Salata AC, Cardoso AI, Evangelista RM, Magro FO. Uso de ácido ascórbico e cloreto de cálcio na qualidade de repolho minimamente processado. Hortic Bras. 2014;32(4):391-397, doi: 10.1590/S0102053620140000400004.

35. Godoy AR, Salata AC, Cardoso AII, Evangelista RM, Kano C, Higuti ARO. Produção e qualidade póscolheita de couve-flor em função de doses de potássio em cobertura. Sci Agr Parana. 2012;11(2):33-42, doi: 10.1818/sap.v11i2.4782.

36. Chitarra MIF, Chitarra AB. Pós-colheita de frutas e hortaliças: glossário. Lavras: UFLA; 2006. 256 p.

37. Sanches AG, Costa JM, Silva MB da, Moreira EGS. Utilização de radiação gama e amido de milho no armazenamento pós-colheita das folhas de couve manteiga. Rev Agric Neotrop. 2016;3(4):24-31, doi: 10.32404/rean.v3i4.1186.

38. Pereira EM, Maria YMG dos, Leite-Filho MT, Fragoso SP, Pereira BBM. Qualidade pós-colheita de frutas e hortaliças cultivadas de forma orgânica. Rev Verde Agroecol Desenvolv Sustentável. 2015;10(2):56-60, doi: 10.18378/rvads.v10i2.3441. 
39. Luengo RFA, Parmagnani RM, Parente MR, Lima MFBF. Tabela de composição nutricional das hortaliças. 2nd ed. Brasília: Embrapa Hortaliças; 2011. 4 p.

40. Von Elbe JH. Colorantes. In: Fennema OW. Química de los alimentos. 2nd ed. Zaragoza: Wisconsin Madison; 2000. p. 782-99.

41. Padula ML, Carciofi BAM, Dannenhauer CE, Stringari GB, Monteiro AR. Influência de diferentes tipos de embalagens nas características físico-químicas e composição gasosa de brócolis (Brassica oleracea L. var Itálica) orgânicos minimamente processados e armazenados sob refrigeração. Aliment e Nutr. 2006;17(3):259-268.

42. Taiz L, Zeiger E. Fisiologia vegetal. 4. ed. Porto Alegre: Artmed; 2009. 848 p.

43. Von Elbe JHE, Schwartz SJ. Colorants. In: Fennema OR. Food chemistry. 3rd. ed. New York: Marcel Dekker; 1996. p. 651-722.

44. Carvalho PGB, Machado CMM, Moretti CL, Fonseca MEDN. Hortaliças como alimentos funcionais. Hortic Bras. 2006;24(4):397-404, doi: 10.1590/S0102-05362006000400001.

45. Rodriguez-Amaya DB, Kimura M, Amaya-Farfan J. Fontes brasileiras de carotenoides: tabela brasileira de composição de carotenoides em alimentos. Brasília: MMA/SBF; 2008.100 p.

46. Wahid A. Physiological implications of metabolite biosynthesis for net assimilation and heat-stress tolerance of sugarcane (Saccharum officinarum) sprouts. J Plant Res. 2007;120(2):219-228, doi: 10.1007/s10265-006-0040-5.

47. Kong JM, Chia LS, Goh NK, Chia TF, Brouillard R. Analysis and biological activities of anthocyanins. Phytochemistry. 2003;64(5):923-933, doi: 10.1016/s0031-9422(03)00438-2.

48. Velosos CCA, Souza FRS de, Pereira WLM, Tenório AR de M. Relações cálcio, magnésio $\varepsilon$ potássio sobre produção de matéria seca de milho. Acta Amaz. 2001;31(2):193-204, doi: 10.1590/180943922001312204.

49. Zambrosi FCB, Alleoni LRF, Caires EF. Aplicação de gesso agrícola e especiação iônica da solução de um Latossolo sob sistema plantio direto. Ciência Rural. 2007;37(1):110-117, doi: 10.1590/S010384782007000100018

50. Demattê JLI. Ação do gesso e do calcário na relação cálcio: magnésio do solo e na produtividade da canade-açúcar. Inf Agron. 2011;136:11-16.

51. Marschner P. Mineral nutrition of higher plants. 3rd ed. Australia: Elsevier; 2012. 651 p.

52. Soares MM, Bardiviesso DM, Ferreira W, Barbosa S, Barcelos MN. Adubação de cobertura com enxofre na cultura da rúcula. Rev Agric Neotrop. 2017;4(1):49-52.

53. Sediyama MAN, Santos MR, Vidigal SM, Salgado LT, Pedrosa MW, Jacob LL. Produtividade e estado nutricional do quiabeiro em função da densidade populacional e do biofertilizante suíno. Bragantia. 2009;68(4):913-920, doi: 10.1590/S0006-87052009000400011.

54. Henz GP, Mattos LM. Manuseio pós-colheita de rúcula. Brasília: Embrapa Hortaliças; 2008. 5 p. (Comunicado Técnico; n. 64).

55. Moreira MA, Vidigal SM. Diagnóstico de nitrogênio por medidores portáteis para uso na cultura do repolho. 2009. 5 p. (Circular técnica EPAMIG; n. 53).

56. Ferreira MMM, Ferreira GB, Fontes PCR, Dantas JP. Qualidade do tomate em função de doses de nitrogênio e da adubação orgânica em duas estações. Hortic Bras. 2006;24(2):141-145, doi: 10.1590/S0102-05362006000200003.

57. Pôrto ML, Puiatti M, Fontes PCR, Cecon PR, Alves J do C, Arruda JA de. Índice SPAD para o diagnóstico do estado de nitrogênio na cultura da abobrinha. Hortic Bras. 2011;29(3):311-315, doi: 10.1590/S010205362011000300009 .

58. Gobbo-Neto L, Lopes NP. Plantas medicinais: fatores de influência no conteúdo de metabólitos secundários. Quím Nova, 2007;30(2):374-381, doi: 10.1590/S010040422007000200026.

59. Takahashi H, Kopriva S, Giordano M, Saito K, Hell R. Sulfur assimilation in photosynthetic organisms: molecular functions and regulations of transporters and assimilatory enzimes. Ann Ver Plant Biol. 2011;62:157-184, doi: 10.1146/annurev-arplant-042110-103921 